\title{
Pengaruh Keahlian Profesional, Independensi, Tingkat Pendidikan dan Pengalaman Kerja terhadap Kinerja Pengawas Kas BPR
}

\author{
Hanafi Cahyadi ${ }^{1}$ \\ Fakultas Ekonomi dan Bisnis \\ Universitas Udayana, Indonesia
}

\author{
Made Gede Wirakusuma² \\ Fakultas Ekonomi dan Bisnis \\ Universitas Udayana, Indonesia
}

\begin{abstract}
Surel : hanafi.dragon@gmail.com
ABSTRAK

Tujuan dari penelitian ini adalah untuk mengetahui pengaruh keahlian profesional, independensi, tingkat pendidikan dan pengalaman kerja terhadap kinerja pengawas kas BPR BPR Lestari Bali. Populasi dalam penelitian ini adalah seluruh karyawan yang bekerja pada PT BPR Lestari Bali. Teknik pengumpulan sampel yang digunakan adalah metode purposive sampling. Jumlah sampel yang ditentukan adalah sebanyak 31 orang Pengawas Kas pada PT BPR Lestari Bali. Teknik analisis data yang digunakan adalah Analisis regresi linier berganda. Hasil analisis menunjukkan bahwa keahlian profesional, independensi, tingkat pendidikan dan pengalaman kerja berpengaruh positif dan signifikan terhadap kinerja pengawas kas BPR. Hal ini mengindikasikan bahwa semakin tinggi keahlian profesional pengawas kas, semakin tinggi sikap independensi pengawas kas, semakin tinggi tingkat pendidikan dan semakin tinggi pengalaman kerja yang dimiliki seorang pengawas kas maka akan semakin meningkatkan kinerja pengawas kas BPR pada BPR Lestari Bali.
\end{abstract}

Kata Kunci: Keahlian Profesional; Independensi; Pendidikan; Pengalaman; Kinerja.

\section{The Influence of Professional Expertise, Independence, Level of Education and Work Experience on the Performance of BPR Cash Supervisors}

\footnotetext{
ABSTRACT

The purpose of this study was to determine the effect of professional expertise, independence, level of education and work experience on the performance of BPR Lestari Bali's cash supervisors. The sample collection technique used is the purposive sampling method. The determined number of samples was 31 Cash Supervisors at PT BPR Lestari Bali. The data analysis technique used is multiple linear regression analysis. The analysis showed that professional expertise, independence, level of education and work experience had a positive and significant effect on the performance of BPR cash supervisors. This indicates that the higher the professional expertise of the cash supervisor, the higher the independence attitude of the cash supervisor, the higher the level of education and the higher work experience a cash supervisor has, the more the performance of the BPR's cash supervisor in BPR Lestari Bali.

Keywords: $\quad$ Professional Expertise; Independence; Education; Experience; The performance.
}

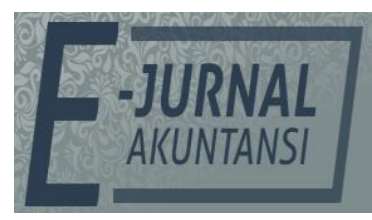

e-ISSN 2302-8556

Vol. 30 No. 11

Denpasar, Nopember 2020

Hal. 2767-2779

DOI:

10.24843/EJA.2020.v30.i11.p05

PENGUTIPAN:

Cahyadi, H. \& Wirakusuma, M.G. (2020). Pengaruh

Keahlian Profesional, Independensi, Tingkat Pendidikan dan Pengalaman Kerja terhadap Kinerja Pengawas Kas BPR. E-Jurnal Akuntansi, 30(11), 2767-2779

RIWAYAT ARTIKEL: Artikel Masuk: 13 Februari 2020 Artikel Diterima: 5 Agustus 2020

Artikel dapat diakses : https://ojs.unud.ac.id/index.php/Akuntansi/index 


\section{PENDAHULUAN}

Tidak banyak lembaga keuangan di Indonesia yang berhasil mencapai prestasi seperti BPR Lestari, terlebih dengan adanya jumlah lembaga keuangan yang begitu banyak yang mengakibatkan persaingan yang begitu ketat. Akan tetapi, BPR Lestari bisa berkembang dan memiliki kinerja sangat bagus (Krisnayanti \& Riana, 2015; Suryadharma, Adi et al., 2016). Artinya, BPR Lestari tetap bisa mempertahankan eksistensinya meskipun berhadapan langsung dengan bankbank umum yang memiliki aset lebih besar darinya. BPR Lestari membuktikan walaupun dari segi jasa yang ditawarkan tidak selengkap bank umum, namun BPR bisa mendapat kepercayaan dari masyarakat dan mampu terus berkembang untuk mendukung pertumbuhan ekonomi Indonesia. Hal ini membuktikan bahwa persaingan tidak lagi sebatas produk perbankan, namun service, human capital, teknologi informasi dan faktor kinerja pengawas kas BPR juga menjadi penentu keberhasilan perusahaan (Ahmed \& Rugami, 2019; Ali et al., 2012).

Auditor bertanggung jawab untuk merencanakan dan melasksanakan audit untuk memperoleh keyakinan memadai tentang apakah laporan keuangan bebas dari salah saji material baik yang disebabkan oleh kecurangan atau kekeliruan (A. W. Putra, 2018). Menurut Albrecht et al. (1984) Internal Audit adalah pelaksana audit/auditor yang menjalankan tugas di dalam perusahaan untuk mengetahui sejauh mana prosedur dan kebijakan yang telah dibentuk sebelumnya dipatuhi, menetapkan apakah pengelolaan akan aset organisasi/perusahaan sudah dilaksanakan dengan baik, menetapkan seberapa efektif dan efisien dari prosedur kegiatan organisasi/perusahaan, serta menilai keefektivitasan informasi yang diproduksi oleh tiap unit di dalam organisasi/perusahaan.

Fenomena Keberhasilan BPR Lestari tentunya tidak terlepas dari peran penting kinerja pengawas kas BPR. Hal tersebut dapat dilihat pada tugas dan tanggung jawab Satuan Kerja Auditor Internal (SKAI) pada BPR Lestari Bali yang sangat kompleks. Jika ditinjau dari tugas dan tanggung jawab pada SKAI BPR Lestari, maka dapat disimpulkan bahwa tugas pemeriksaan dan wewenang yang dimiliki oleh internal auditor merupakan kegiatan yang sangat penting, disini auditor dituntut agar memiliki kualitas yang baik. Apabila terjadi penyimpangan-penyimpangan, internal auditor harus segera melakukan tindakan koreksi sehingga dengan adanya auditor diharapkan kesalahan-kesalahan, penyelewengan serta kekeliruan dapat diminimalisir agar tujuan perusahaan dapat tercapai (Drábková, 2016; Haliah, 2015).

Target kinerja pengawas kas BPR pada BPR Lestari yang kompleks tersebut dapat tercapai apabila Pengawas kas memiliki keahlian profesional, sikap independensi, pengalaman kerja, dan tingkat pendidikan yang tinggi. Pengawas kas dalam menjalankan tugasnya harus mempunyai keahlian profesional yang baik dan mematuhi kode etik profesi (Prabowo \& Widanaputra, 2018).

Dengan keahlian profesional yang dimiliki seorang pengawas maka tugas-tugas pemeriksaan dan audit akan berjalan dengan baik dengan hasil yang maksimal. Agar mempunyai keahlian profesional. Menurut Akmal (2006), Pengawas kas harus memiliki kemampuan profesional yang berarti seorang Pengawas kas harus mempergunakan keahlian dan ketelitian dalam 
menjalankan profesinya. Pengawas kas diharapkan mampu menilai apakah semua kebijakan telah dilaksanakan dan mengkoreksi segala bentuk penyimpangan yang terjadi dengan keahlian profesional yang dimiliki oleh pengawas.

Penelitian yang dilakukan Dianawati \& Ramantha (2013), membuktikan bahwa keahlian profesional yang dimiliki oleh badan auditor berpengaruh positif dan signifikan terhadap kinerja badan auditor sebagai fungsi internal auditor dalam auditoran kredit. Hal ini akan mengarah pada efektifitas dan kinerja badan auditor yang nantinya akan berpengaruh pada efektivitas struktur pengendalian intern. Namun hasil berbeda diperoleh dalam penelitian Ariani, (2009) yang menyatakan bahwa profesionalisme auditor tidak berpengaruh pada kinerja auditor. Hal ini menunjukkan adanya hasil penelitian terdahulu yang tidak konsisten, sehingga peneliti tertarik melakukan penelitian kembali terkait pengaruh keahlian profesional terhadap kinerja pengawas kas BPR di BPR Lestari Bali.

Selain keahlian profesional, auditor juga diharapan memiliki sikap independensi yang tinggi. Independensi adalah suatu sikap mental yang terbebas dari pengaruh, tidak dikendalikan oleh pihak lain, dan tidak tergantung pada orang lain (A. C. Dewi, 2016). Sebagai seorang Pengawas kas harus menjaga integritas dan obyektifitas dalam melaksanakan tugasnya, serta harus independen dari semua kepentingan atau pengaruh yang tidak layak (Desyanti \& Ratnadi, 2008; Novia \& Ariyanto, 2016). Independensi seorang auditor adalah integritas dari auditor dalam mempertimbangkan fakta dan adanya pertimbangan yang objektif serta tidak memihak dalam merumuskan dan menyatakan pendapat. Integritas merupakan sikap moral yang tidak memihak (Pramono \& Mustkawati, 2016; Wijana \& Ramantha, 2015), jujur (Mahayani \& Merkusiwati, 2016; Rahayu \& Gudono, 2016), memandang dan mengemukakan fakta apa adanya (Yuen et al., 2013).

Menurut Junitayanti (2011), dalam penelitiannya menunjukkan bahwa independensi berpengaruh positif pada kinerja pengawas kas BPR. Namun menurut Dewi (2016) menyatakan bahwa independensi tidak berpengaruh pada kinerja pengawas kas BPR. Hal ini menunjukkan adanya hasil penelitian terdahulu yang tidak konsisten, sehingga peneliti tertarik melakukan penelitian kembali terkait pengaruh independensi terhadap kinerja pengawas kas BPR di BPR Lestari Bali.

Faktor lain yang harus dimiliki oleh seorang Pengawas Kas adalah faktor pendidikan yang tinggi. Dalam penelitian yang dilakukan Styawati (2009), menemukan bahwa variabel tingkat pendidikan auditor menunjukan adanya pengaruh positif dan signifikan sacara parsial terhadap kinerja auditor. Pendidikan merupakan yang sangat penting namun harus diikuti dengan pengalaman kerja yang baik. Menurut (Cloyd, 1997), menyatakan bahwa tingkat pengetahuan seseorang dapat meningkatkan kualitas kerja. Pengetahuan diukur dari seberapa tinggi pendidikan seorang pengawas karena dengan demikian seorang pengawas kas akan mempunyai semakin banyak pengetahuan atau pandangan mengenai bidang yang digelutinya sehingga dapat mengetahui berbagai masalah secara lebih mendalam, selain itu seorang auditor akan lebih mudah dalam mengikuti perkembangan semakin kompleks Harhinto (2004). 
Dalam persaingan dunia kerja sekarang ini yang semakin ketat maka dibutuhkan sebuah tingkat pendidikan yang mumpuni, sehingga lebih mampu bersaing dalam memasuki dunia kerja keorganisasian dengan lebih baik. Semakin tinggi tingkat pendidikan seorang pengawas maka akan bertambahnya pengetahuan, keterampilan, kecakapan, dan kecekatan dalam pengabdian kerjanya dalam sebuah organisasi. Hal ini menunjukkan bahwa ada hubungan positif antara tingkat pendidikan dengan kinerja pengawas. Namun hasil berbeda diperoleh dalam penelitian Kurniawan (2018) yang menemukan hasil bahwa latar belakang pendidikan tidak berpengaruh pada akuntabilitas kinerja yang dihasilkan auditor. Hasil tersebut menunjukkan adanya hasil penelitian terdahulu yang tidak konnsisten, sehingga peneliti tertarik melakukan penelitian kembali terkait pengaruh tingkat pendidikan terhadap kinerja pengawas kas BPR di BPR Lestari Bali.

Kinerja pengawas kas BPR juga dapat dipengaruhi oleh pengalaman kerja yang dimilikinya. Pengalaman kerja seorang Pengawas kas juga akan memberikan ketepatan, keterampilan, dan ketepatan dalam melaksanakan tugasnya, pengalaman kerja memiliki peran penting dalam memprediksi dan menilai kinerja pengawas kas BPR dalam melaksanakan tugasnya. Pengetahuan Pengawas kas tentang audit akan semakin berkembang dengan bertambahnya pengalaman dalam bekerja. Pengalaman kerja akan meningkat seiring dengan semakin meningkatnya kompleksitas kerja termasuk dalam melakukan tugas pemeriksaan. Desyanti \& Ratnadi (2008), menyatakan pengalaman kerja internal auditor memiliki pengaruh secara parsial yang signifikan terhadap efektivitas penerapan struktur pengendalian intern. Semakin banyak pengalaman kerja seseorang atau semakin lamanya waktu orang tersebut untuk masa bekerja akan dapat meningkatkan kemampuan kerja sama atau dengan kata lain akan mempengaruhi peningkatan kinerja orang yang bersangkutan. Hal ini juga diungkapkan oleh Prawitasari \& Badera (2015) yang membuktikan bahwa pengalaman kerja badan auditor berpengaruh positif dan signifikan pada kinerja pengawas kas BPR. Namun hasil berbeda diperoleh pada penelitian Ilhamsyah, (2018) yang menyatakan bahwa pengalaman kerja auditor tidak berpengaruh signifikan terhadap kualitas audit internal. Hal ini menunjukkan adanya hasil penelitian terdahulu yang tidak konsisten, sehingga peneliti tertarik melakukan penelitian kembali terkait pengaruh pengalaman kerja terhadap kinerja pengawas kas BPR.

Keahlian profesional memiliki hubungan yang positif pada kinerja. Hal ini terungkap dalam penelitian yang dilakukan Dianawati \& Ramantha (2013), yang membuktikan bahwa keahlian profesional yang dimiliki oleh badan auditor berpengaruh positif dan signifikan terhadap kinerja badan auditor sebagai fungsi internal auditor dalam auditoran kredit. Hal ini akan mengarah pada efektifitas dan kinerja badan auditor yang nantinya akan berpengaruh pada efektivitas struktur pengendalian intern. Kalbers \& Fogarty (1995) yang menyatakan bahwa internal auditor yang mempunyai keahlian profesional akan merasakan bahwa kinerja bisa menjadikan sesuatu yang mungkin membuat mereka mempersoalkan apabila ada usaha penyelewengan oleh manajemen. Pengujian terhadap pengaruh keahlian profesionalisme terhadap kinerja yang dilakukan 
oleh Kalbers \& Fogarty (1995) membuktikan adanya pengaruh positif walaupun hanya pada dimensi afiliasi komunitas dan tuntutan kemandirian.

$\mathrm{H}_{1}$ : Keahlian profesional berpengaruh positif dan signifikan pada kinerja pengawas kas BPR.

Independensi dapat diartikan bebas dari pengaruh, tidak dikendalikan oleh pihak lain, dan tidak tergantung oleh pihak lain (Halim \& Kusufi, 2014). Menurut Hery (2010) independensi merupakan sikap mandiri dan terpisah dari berbagai kegiatan yang diperiksa yang diperiksa. Setiap Pengawas kas harus memelihara integritas dan obyektivitas dalam tugas profesionalnya. Seorang Pengawas kas yang baik harus memiliki sikap independensi. Sikap independensi dirasa sangat penting dalam melaksanakan audit yang efektif (Jr, 2008). Menurut Junitayanti (2011), dalam penelitiannya menunjukkan bahwa independensi berpengaruh pada kinerja pengawas kas BPR sebagai fungsi internal auditor. desyanti \& Ratnadi (2008), juga menemukan bahwa variabel independensi berpengaruh pada kinerja auditor. Menurut Allen et al. (2005), menyatakan bahwa independensi terbukti berpengaruh positif terhadap kinerja auditor, yang dapat disimpilkan bahwa semakin tinggi independensi auditor maka kinerja auditor yang dihasilkan akan semakin lebih baik.

$\mathrm{H}_{2}$ : Independensi berpengaruh positif dan signifikan pada kinerja pengawas kas BPR.

Pendidikan sebagai optimalisasi sumber daya manusia yang cenderung lebih bersifat formal mengingat antisipasi kemampuan dan keahlian individu yang harus dipersiapkan bagi kepentingan jabatan yang akan datang untuk mengantisipasi perubahan yang mungkin terjadi tanpa direncanakan atau direncanakan (Rahma, 2012). Penelitian yang dilakukan oleh Rahma (2012) membuktikan bahwa tingkat pendidikan berpengaruh signifikan terhadap kualitas audit.

Penelitian yang dilakukan oleh Murtini \& Juliarsa (2017), membuktikan bahwa variabel tingkat pendidikan menunjukan adanya pengaruh positif dan signifikan pada kinerja pengawas kas BPR. Pendidikan dan pelatihan adalah suatu proses kegiatan dari suatu perusahaan yang bertujuan untuk membenahi dan mengembangkan sikap, perilaku, keterampilan dan pengetahuan serta kecerdasan sumber daya manusia sesuai keinginan dari perusahaan yang bersangkutan. Berdasarkan hasil penelitian tersebut, maka dapat diajukan hipotesis sebagai berikut.

$\mathrm{H}_{3}$ : Tingkat pendidikan berpengaruh positif dan signifikan pada kinerja pengawas kas BPR.

Pengalaman kerja merupakan salah satu atribut penting yang harus dimiliki oleh internal auditor karena semakain banyak pengalaman kerja, semakin obyektif auditor melaukan pemeriksaan dan semakin baik baik kualitas audit dan hasil pemeriksaan yang dilakukan (Putra \& Wisadha, 2013). Pengalaman kerja seorang auditor akan menambah keterampilan dan kecepatan dalam melaksanakan tugas-tugas serta mengurangi tingkat kesalahan.

Pengalaman kerja berpengaruh positif pada kinerja. Hal ini terungkap dalam penelitian yang dilakukan oleh (Dewi, 2011) yang menunjukkan bahwa pengalaman kerja berpengaruh positif terhadap penerapan efektivitas struktur pengendalian intern BPR di Kota Denpasar. Hal ini juga diungkapkan oleh 
Prawitasari \& Badera (2015) yang membuktikan bahwa pengalaman kerja badan auditor berpengaruh positif dan signifikan pada kinerja pengawas kas BPR.

$\mathrm{H}_{4}$ : Pengalaman kerja berpengaruh positif dan signifikan pada kinerja pengawas kas BPR.

\section{METODE PENELITIAN}

Lokasi penelitian atau ruang lingkup wilayah penelitian ini dilakukan pada BPR Lestari yang berada di pulau Bali. Populasi dalam penelitian ini adalah seluruh karyawan yang bekerja pada PT BPR Lestari Bali. PT BPR Lestari Bali berjumlah 15 kantor dengan jumlah karyawan berdasarkan survei pendahuluan sebanyak 436 orang dan didapatkan 31 orang Pengawas Kas untuk dijadikan responden. Teknik pengambilan sampel yang digunakan dalam penelitian ini adalah teknik nonprobability sampling dengan metode purposive sampling, yaitu teknik penentuan sampel dengan pertimbangan atau kriteria tertentu. Adapun kriteria yang dijadikan pemilihan anggota sampel pada penelitian ini adalah Pengawas Kas pada PT BPR Lestari Bali. Jumlah sampel pada penelitian ini adalah 31 orang. Teknik analisis yang digunakan dalam penelitian ini adalah teknik analisis regresi linear berganda. Analisis regresi linear berganda dipergunakan untuk mengetahui pengaruh variabel bebas terhadap variabel terikatnya. Teknik ini menggunakan program Statistical Package for Social Science (SPSS) untuk mengetahui pengaruh keahlian profesional, independensi, tingkat pendidikan, dan pengalaman kerja pada kinerja pengawas kas BPR BPR Lestari Bali. Hasil analisis dinyatakan dalam bentuk persamaan regresi linear berganda sebagai berikut (Sugiyono, 2017).

$$
\hat{Y}=\alpha+\beta_{1} X_{1}+\beta_{2} X_{2}+\beta_{3} X_{3}+\beta_{4} X_{4}+\varepsilon
$$

Keterangan :

$$
\begin{array}{ll}
\mathrm{Y} & =\text { Kinerja pengawas kas BPR } \\
\mathrm{X}_{1} & =\text { Keahlian Profesional } \\
\mathrm{X}_{2} & =\text { Independensi } \\
\mathrm{X}_{3} & =\text { Tingkat Pendidikan } \\
\mathrm{X}_{4} & =\text { Pengalaman Kerja } \\
\beta_{1} \text { s.d } \beta_{4} & =\text { Koefesien Regresi } \\
\alpha & =\text { Konstanta } \\
\varepsilon & =\text { Standard error }
\end{array}
$$

\section{HASIL DAN PEMBAHASAN}

Statistik deskriptif bertujuan untuk memberikan informasi mengenai karakteristik variabel-variabel penelitian yaitu jumlah amata nilai minimum, nilai maksimum, nilai mean, dan standar deviasi. Untuk mengukur nilai sentral dari distribusi data dapat dilakukan dengan pengukuran rata-rata (mean) sedangkan standar deviasi merupakan perbedaan nilai data yang diteliti dengan nilai rata-ratanya. Hasil statistik deskriptif dapat dilihat pada Tabel 1.

Variabel keahlian profesional memiliki nilai minimum sebesar 24 dan nilai maksimum sebesar 35. Variabel keahlian profesional yang diukur dengan 7 item pernyataan dengan bantuan skala likert 5 poin memiliki nilai rata-rata sebesar 31,00 , dengan nilai standar deviasi variabel keahlian profesional sebesar 2,72. Hal 
ini berarti nilai standar deviasi ini lebih rendah dibandingkan dengan nilai ratarata, yang artinya sebaran data terkait keahlian profesional sudah merata.

Tabel 1. Hasil Statistik Deskriptif Variabel Penelitian

\begin{tabular}{llllll}
\hline & $\mathrm{N}$ & Minimum & Maximum & Mean & Std. Deviation \\
\hline Keahlian Profesional & 31 & 24.00 & 35.00 & 31.0000 & 2.72029 \\
Independensi & 31 & 25.00 & 40.00 & 34.7419 & 3.25543 \\
Tingkat Pendidikan & 31 & 25.00 & 35.00 & 30.6129 & 2.83640 \\
Pengalaman Kerja & 31 & 29.00 & 40.00 & 34.0968 & 2.76110 \\
Kinerja & 31 & 26.00 & 40.00 & 34.4839 & 3.08622 \\
Valid N (listwise) & 31 & & & &
\end{tabular}

Sumber: Data Penelitian, 2020

Variabel independensi memiliki nilai minimum sebesar 25 dan nilai maksimum sebesar 40. Variabel independensi yang diukur dengan 8 item pernyataan dengan bantuan skala likert 5 poin memiliki nilai rata-rata sebesar 34,74, dengan nilai standar deviasi variabel independensi sebesar 3,25. Hal ini berarti nilai standar deviasi ini lebih rendah dibandingkan dengan nilai rata-rata, yang artinya sebaran data terkait independensi sudah merata.

Variabel tingkat pendidikan memiliki nilai minimum sebesar 25 dan nilai maksimum sebesar 35. Variabel tingkat pendidikan yang diukur dengan 7 item pernyataan dengan bantuan skala likert 5 poin memiliki nilai rata-rata sebesar 30,61 , dengan nilai standar deviasi variabel tingkat pendidikan sebesar 2,836. Hal ini berarti nilai standar deviasi ini lebih rendah dibandingkan dengan nilai ratarata, yang artinya sebaran data terkait tingkat pendidikan sudah merata.

Variabel pengalaman kerja memiliki nilai minimum sebesar 29 dan nilai maksimum sebesar 40. Variabel pengalaman kerja yang diukur dengan 8 item pernyataan dengan bantuan skala likert 5 poin memiliki nilai rata-rata sebesar 34,09 , dengan nilai standar deviasi variabel pengalaman kerja sebesar 2,761. Hal ini berarti nilai standar deviasi ini lebih rendah dibandingkan dengan nilai ratarata, yang artinya sebaran data terkait pengalaman kerja sudah merata.

Variabel kinerja pengawas kas BPR memiliki nilai minimum sebesar 26 dan nilai maksimum sebesar 40. Variabel kinerja pengawas kas BPR yang diukur dengan 8 item pernyataan dengan bantuan skala likert 5 poin memiliki nilai ratarata sebesar 34,48, dengan nilai standar deviasi variabel kinerja pengawas kas BPR sebesar 3,086. Hal ini berarti nilai standar deviasi ini lebih rendah dibandingkan dengan nilai rata-rata, yang artinya sebaran data terkait kinerja pengawas kas BPR sudah merata.

Perhitungan koefisien regresi linier berganda dilakukan dengan analisis regresi melalui software SPSS 18.0 for Windows, diperoleh hasil yang ditunjukan pada Tabel 2.

Berdasarkan hasil analisis regresi linier berganda seperti yang disajikan pada Tabel 2, maka dapat dibuat persamaan regresi sebagai berikut.

$$
Y=-3,833+0,264 X_{1}+0,306 X_{2}+0,308 X_{3}+0,295 X_{4}
$$

Koefisien regresi keahlian profesional $\left(\beta_{1}\right)$ sebesar 0,264 berarti apabila keahlian profesional $\left(\mathrm{X}_{1}\right)$ dinaikkan satu satuan dan variabel lainya tidak berubah maka kinerja pengawas kas BPR (Y) naik sebesar 0,264 satuan, artinya setiap peningkatan keahlian profesional dapat meningkatkan kinerja pengawas kas BPR. 
Koefisien regresi independensi $\left(\beta_{2}\right)$ sebesar 0,306 berarti apabila independensi $\left(\mathrm{X}_{2}\right)$ dinaikkan satu satuan dan variabel lainya tidak berubah maka kinerja pengawas kas BPR (Y) naik sebesar 0,306 satuan, artinya setiap peningkatan independensi dapat meningkatkan kinerja pengawas kas BPR.

Koefisien regresi tingkat pendidikan $\left(\beta_{3}\right)$ sebesar 0,308 berarti apabila tingkat pendidikan $\left(X_{3}\right)$ dinaikkan satu satuan dan variabel lainya tidak berubah maka kinerja pengawas kas BPR (Y) naik sebesar 0,308 satuan, artinya setiap peningkatan tingkat pendidikan dapat meningkatkan kinerja pengawas kas BPR.

Koefisien regresi pengalaman kerja $\left(\beta_{4}\right)$ sebesar 0,295 berarti apabila pengalaman kerja $\left(\mathrm{X}_{4}\right)$ dinaikkan satu satuan dan variabel lainya tidak berubah maka kinerja pengawas kas BPR (Y) naik sebesar 0,295 satuan, artinya setiap peningkatan pengalaman kerja dapat meningkatkan kinerja pengawas kas BPR.

Tabel 2. Hasil Analisis Regresi Linier Berganda

\begin{tabular}{|c|c|c|c|c|c|}
\hline \multirow[t]{2}{*}{$\overline{\text { Model }}$} & \multicolumn{2}{|c|}{$\begin{array}{l}\text { Unstandardized } \\
\text { Coefficients }\end{array}$} & \multirow{2}{*}{$\begin{array}{l}\text { Standardized } \\
\text { Coefficients } \\
\text { Beta }\end{array}$} & \multirow[b]{2}{*}{$t$} & \multirow[b]{2}{*}{ Sig. } \\
\hline & $\bar{B}$ & Std. Error & & & \\
\hline 1 (Constant) & $-3,833$ & 3,012 & & $-1,273$ & 0,214 \\
\hline Keahlian profesional & 0,264 & 0,102 & 0,232 & 2,587 & 0,016 \\
\hline Independensi & 0,306 & 0,131 & 0,323 & 2,334 & 0,028 \\
\hline Tingkat pendidikan & 0,308 & 0,121 & 0,283 & 2,556 & 0,017 \\
\hline Pengalaman kerja & 0,295 & 0,133 & 0,264 & 2,215 & 0,036 \\
\hline R Square & 0,882 & & & & \\
\hline Adjusted R Square & 0,864 & & & & \\
\hline F Statistik & 48,625 & & & & \\
\hline Signifikansi Uji F & 0,000 & & & & \\
\hline
\end{tabular}

Sumber: Data Penelitian, 2020

Koefisien determinasi $\left(\mathrm{R}^{2}\right)$ digunakan untuk mengetahui dan mengukur kemampuan model dalam menerangkan variasi variabel independen. Peneliti menggunakan nilai adjusted $\mathrm{R}^{2}$ pada saat mengevaluasi yang mana model regresi terbaik, karena tidak seperti $R^{2}$, nilai adjusted $R^{2}$ dapat naik atau turun apabila satu variabel independen ditambahkan ke dalam model. Adapun hasil uji koefisien determinasi dapat dilihat pada Tabel 3.

Tabel 3. Hasil Uji Koefisien Determinasi $\left(\mathbf{R}^{2}\right)$

\begin{tabular}{|c|c|c|c|c|}
\hline Model & $\mathrm{R}$ & R Square & Adjusted R Square & $\begin{array}{l}\text { Std. Error of the } \\
\text { Estimate }\end{array}$ \\
\hline 1 & $0,939 a$ & 0,882 & 0,864 & 48,625 \\
\hline
\end{tabular}

Sumber: Data Penelitian, 2020

Tabel 3, menunjukkan bahwa besarnya pengaruh variabel bebas terhadap variabel terikat yang ditunjukkan oleh nilai determinasi total ( $\mathrm{R}$ Square) sebesar 0,882 mempunyai arti bahwa sebesar $88,2 \%$ variasi Kinerja pengawas kas BPR dipengaruhi oleh variasi Keahlian profesional, Independensi, Tingkat pendidikan, dan Pengalaman kerja, sedangkan sisanya sebesar $11,8 \%$ djelaskan oleh faktor lain yang tidak dimasukkan ke dalam model.

Uji ketepatan model regresi bertujuan untuk mengetahui apakah semua variabel bebas yang diidentifikasi (keahlian profesional, independensi, tingkat pendidikan, dan pengalaman kerja) tepat digunakan memprediksi kinerja pengawas kas BPR. Uji ini sering juga disebut dengan uji $F$ yang dapat dilihat pada Tabel 4, berikut. 
Tabel 4. Hasil Uji F

\begin{tabular}{lllllll}
\hline Model & & Sum of Squares & $d f$ & Mean Square & $F$ & Sig. \\
\hline 1 & Regression & 252.049 & 4 & 63.012 & 48.625 & $.000^{\mathrm{b}}$ \\
& Residual & 33.693 & 26 & 1.296 & & \\
& Total & 285.742 & 30 & & & \\
\hline
\end{tabular}

Sumber: Data Penelitian, 2020

Hasil uji F (Ftest) pada Tabel 4, menunjukkan bahwa nilai $F_{\text {hitung }}$ sebesar 48,625, dengan nilai sig. 0,000 $<0,05$, maka Ho ditolak dan $\mathrm{H}_{1}$ diterima. Kesimpulannya, pada kelompok yang diuji memiliki perbedaan yang nyata (signifikan). Hasil ini mempunyai arti bahwa ada pengaruh signifikan antara faktor Keahlian profesional, Independensi, Tingkat pendidikan, dan Pengalaman kerja secara simultan terhadap kinerja pengawas kas BPR.

Pengaruh variabel keahlian profesional, independensi, tingkat pendidikan, dan pengalaman kerja terhadap kinerja pengawas kas BPRdiuji dengan menggunakan Uji t. Kriteria pengujian untuk menjelaskan interpretasi pengaruh antar masing-masing variabel yakni apabila nilai signifikansi $<0,05$ maka $\mathrm{H}_{0}$ ditolak dan $\mathrm{H}_{1}$ diterima. Sebaliknya, jika nilai signifikansi > 0,05 maka $\mathrm{H}_{0}$ diterima dan $\mathrm{H}_{1}$ ditolak.

Berdasarkan hasil analisis pengaruh Keahlian profesional terhadap Kinerja pengawas kas BPR diperoleh nilai Signifikasi sebesar 0,016 dengan nilai koefisien regresi positif sebesar 0,264. Nilai Signifikansi 0,016 < 0,050 mengindikasikan bahwa $\mathrm{H}_{1}$ diterima. Hasil ini mempunyai arti bahwa Keahlian profesional berpengaruh positif dan signifikan terhadap Kinerja pengawas kas BPR.

Hasil analisis menunjukkan bahwa keahlian profesional berpengaruh positif dan signifikan terhadap kinerja pengawas kas BPR. Hal ini mengindikasikan bahwa, semakin tinggi keahlian profesional Pengawas, maka akan semakin meningkatkan kinerja pengawas kas BPR pada BPR Lestari Bali. Penelitian ini mendukung beberapa hasil penelitian sebelumnya dan konsisten dengan hasil penelitian yang dilakukan oleh Dianawati \& Ramantha (2013) dan Kalbers \& Fogarty (1995) yang membuktikan bahwa keahlian profesional yang dimiliki oleh badan auditor berpengaruh positif dan signifikan terhadap kinerja badan auditor sebagai fungsi auditor internal dalam auditoran kredit. Hal ini akan mengarah pada efektifitas dan kinerja badan auditor yang nantinya akan berpengaruh pada efektivitas struktur pengendalian internal.

Berdasarkan hasil analisis pengaruh independensi terhadap kinerja pengawas kas BPR diperoleh nilai signifikansi sebesar 0,028 dengan nilai koefisien regresi positif sebesar 0,306. Nilai Signifikansi 0,028<0,05 mengindikasikan bahwa $\mathrm{H}_{2}$ diterima. Hasil ini mempunyai arti bahwa Independensi berpengaruh positif dan signifikan terhadap Kinerja pengawas kas BPR.

Hasil analisis menunjukkan bahwa independensi berpengaruh positif dan signifikan terhadap kinerja pengawas kas BPR. Hal ini mengindikasikan bahwa, semakin tinggi sikap independensi Pengawas, maka akan semakin meningkatkan kinerja pengawas kas BPR pada BPR Lestari Bali. Penelitian ini mendukung hasil penelitian yang dilakukan oleh Junitayanti (2011), yang dalam penelitiannya menunjukkan bahwa independensi berpengaruh pada kinerja pengawas kas BPR sebagai fungsi internal auditor. Hasil ini juga mendukung 
temuan Allen et al., (2005) dan Desyanti \& Ratnadi (2008) yang mengatakan bahwa independensi terbukti berpengaruh positif terhadap kinerja auditor, yang dapat disimpilkan bahwa semakin tinggi independensi auditor maka kinerja auditor yang dihasilkan akan semakin lebih baik.

Berdasarkan hasil analisis pengaruh Tingkat pendidikan terhadap Kinerja pengawas kas BPR diperoleh nilai signifikansi sebesar 0,017 dengan nilai koefisien regresi positif sebesar 0,308. Nilai signifikansi 0,017 $<0,050$ mengindikasikan bahwa $\mathrm{H}_{3}$ diterima. Hasil ini mempunyai arti bahwa Tingkat pendidikan berpengaruh positif dan signifikan terhadap Kinerja pengawas kas BPR. Hasil analisis menunjukkan bahwa tingkat pendidikan berpengaruh positif dan signifikan terhadap kinerja pengawas kas BPR. Hal ini mengindikasikan bahwa, semakin tinggi tingkat pendidikan yang dimiliki Pengawas, maka pengetahuan dan pemahamannya akan semakin banyak, sehingga akan semakin meningkatkan kinerja pengawas kas BPR tersebut pada BPR Lestari Bali.

Penelitian ini mendukung hasil penelitian yang dilakukan oleh Rahma (2012), membuktikan bahwa tingkat pendidikan berpengaruh signifikan terhadap kualitas audit. Hasil ini juga sesuai dengan enelitian yang dilakukan oleh Murtini \& Juliarsa (2017), membuktikan bahwa variabel tingkat pendidikan menunjukan adanya pengaruh positif dan signifikan pada kinerja pengawas kas BPR. Pendidikan dan pelatihan adalah suatu proses kegiatan dari suatu perusahaan yang bertujuan untuk membenahi dan mengembangkan sikap, perilaku, keterampilan dan pengetahuan serta kecerdasan sumber daya manusia sesuai keinginan dari perusahaan yang bersangkutan.

Berdasarkan hasil analisis pengaruh Pengalaman kerja terhadap Kinerja pengawas kas BPR diperoleh nilai signifikansi sebesar 0,036 dengan nilai koefisien regresi positif sebesar 0,295. Nilai signifikansi 0,036 $<0,05$ mengindikasikan bahwa $\mathrm{H}_{4}$ diterima. Hasil ini mempunyai arti bahwa Pengalaman kerja berpengaruh positif dan signifikan terhadap Kinerja pengawas kas BPR. Hasil analisis menunjukkan bahwa pengalaman kerja berpengaruh positif dan signifikan terhadap kinerja pengawas kas BPR. Hal ini mengindikasikan bahwa, semakin tinggi pengalaman kerja yang dimiliki Pengawas, maka akan membuat Pengawas kas semakin memahami pekerjaannya, sehingga dapat semakin meningkatkan kinerja pengawas kas BPR pada BPR Lestari Bali.

Hasil penelitian ini sesuai dengan temuan Putra \& Wisadha (2013) yang menyatakan pengalaman kerja berpengaruh positif pada kinerja, yaitu pengalaman kerja seorang auditor akan menambah keterampilan dan kecepatan dalam melaksanakan tugas-tugas serta mengurangi tingkat kesalahan. Penelitian ini juga mendukung beberapa hasil penelitian sebelumnya dan konsisten dengan hasil penelitian yang dilakukan oleh Dewi (2011) dan Prawitasari \& Badera (2015) yang membuktikan bahwa pengalaman kerja badan auditor berpengaruh positif dan signifikan pada kinerja pengawas kas BPR.

\section{SIMPULAN}

Penelitian yang dilakukan diharapkan dapat memberikan kontribusi mengenai pengaruh keahlian profesional, independensi, pemahaman internal auditor dan pengalaman kerja terhadap kinerja pengawas kas BPR pada BPR Lestari Bali. 
Hasil uji hipotesis dalam penelitian ini ditemukan bahwa keahlian profesional, independensi, tingkat pendidikan dan pengalaman kerja secara statistik mampu berpengaruh positif pada meningkatnya kinerja pengawas kas BPR pada BPR Lestari Bali.

Sebuah organisasi memerlukan adanya auditor independen yang bertugas untuk menguji dan memperkecil kecurangan agent. Penelitian ini memberikan implikasi bagi BPR Lestari Bali sebagai pertimbangan dan pengetahuan mengenai kinerja pengawas kas BPR serta faktor-faktor yang memengaruhinya. BPR Lestari Bali dapat mengevaluasi keahlian profesional, independensi, tingkat pendidikan dan pengalaman kerja yang dimiliki oleh Pengawas karena hal tersebut dapat mempengaruhi kinerja pengawas kas BPR dalam pada BPR Lestari Bali.

\section{REFERENSI}

Ahmed, A. F., \& Rugami, M. (2019). Corporate Governance and Perfomance of Savings and Credit Cooperative Societies in Kilifi County, Kenya. International Academic Journal of Economics and Finance, 3(3), 61-79.

Akmal. (2006). Pemeriksaan Intern. PT Indeks Kelompok Gramedia.

Albrecht, S., Howe, K., \& Romney, M. (1984). Deterring fraud: the internal auditor's perspective. Institute of Internal Auditors Research Foundation.

Ali, S. M., Shaharudin, M. R., \& Anuar, A. (2012). The association between job positions, work experience and career satisfaction: The case of Malaysian's academic staff. Asian Social Science. https:// doi.org/10.5539/ass.v8n10p35

Allen, M. F., Linville, M., \& Stott, D. M. (2005). The Effect of Litigation on Independent Auditor Selection. American Journal of Business, 20(1), 37-45. https:// doi.org/10.1108/19355181200500004

Ariani. (2009). Pengaruh Profesionalisme, Etika Profesi, Tingkat Pendidikan dan Pengalaman Kerja Inspektorat Provinsi Bali. Fakultas Ekonomi dan Bisnis Universitas Udayana.

Cloyd, C. B. (1997). Performance in Tax Research Tasks: The Joint Effects of Knowledge and Accountability. The Accounting Review, 72(1), 111-131.

DESYANTI, N. P. E., \& RATNADI, N. M. D. (2008). Pengaruh Indepensi, keahlian Profesional, dan Pengalaman Kerja Auditor Intern terhadap Efektivitas Penerapan Struktur Pengendalian Intern pada Bank Perkreditan Rakyat di Kabupaten Badung. Jurnal Ilmiah Akuntansi Dan Bisnis, 3(1). https://ojs.unud.ac.id/index.php/jiab/article/view/2561

Dewi, A. C. (2016). Pengaruh Pengalaman Kerja, Kompetensi, Dan Independensi Terhadap Kualitas Audit Dengan Etika Auditor Sebagai Variabel Moderasi (Studi Empiris pada Auditor Internal Inspektorat Provinsi Daerah Istimewa Yogyakarta). Jurnal Universitas Negeri Yogyakarta, 96-107.

Dewi, A. I. (2011). Pengaruh Independsi, Keahlian Profesional, Pengalaman Kerja, Pendidikan dan Pelatihan Auditor Intern Terhadap Efektivitas Penerapan Struktur Pengendalian Intern BPR di Kota Denpasar. Universitas Udayana.

Dianawati, N. M. D., \& Ramantha, W. (2013). Pengaruh Independensi, Keahlian Profesional Dan Pengalaman Kerja Auditor Internal Terhadap Efektivitas Struktur Pengendalian Internal Bank Perkreditan Rakyat Di Kabupaten Gianyar. E-Jurnal Akuntansi, 4(3), 439-450. 
Drábková, Z. (2016). Models of Detection of Manipulated Financial Statements As Part of the Internal Control System of the Entity. ACRN Oxford Journal of Finance and Risk Perspectives, 5(1), 227-235.

Haliah. (2015). Quality of report, Is there a management, and information technology role?. Empirical evidence from West Sulawesi Province, Indonesia. International Journal of Economic Research.

Halim, A., \& Kusufi, M. S. (2014). Akuntansi Sektor Publik: Akuntansi Keuangan Daerah (Edisi 4). Salemba Empat.

Harhinto, T. (2004). Pengaruh Keahlian dan Independensi Terhaap Kualitas Audit Studi Empiris pada KAP di Jawa Timur. Universitas Diponegoro.

Hery. (2010). Potret Profesi Audit Internal. Alfabeta.

Ilhamsyah, F. (2018). Pengaruh Kompetensi, Profesionalisme, Dan Pengalaman Kerja Auditor Terhadap Kualitas Audit Internal Pada Perbankan. Jurnal Akuntansi, 3(1), 1-19.

Jr, R. B. H. (2008). Better internal audit leads to better controls; Is your internal audit activity doing what you and your board of directors want? If not, what steps are you taking to change it? Financial Executive, 24(9), 49+. https://go.gale.com/ps/anonymous?id=GALE\%7CA189068769\&sid=googl eScholar\&v $=2.1 \& i t=r \& l i n k a c c e s s=a b s \& i s s n=08954186 \& p=A O N E \& s w=w$

Junitayanti, W. (2011). Pengaruh Independensi, Keahlian Profesional, Tingkat Pendidikan dan Lingkup Pekerjaan pada Kinerja Badan Auditor sebagai Fungsi Internal Auditor dalam Auditoran Kredit pada Lembaga Perkreditan Desa Sekecamatan Kuta Badung. Universitas Udayana.

Kalbers, L. P., \& Fogarty, T. J. (1995). Profesionalism and Its Consequences: A Study of Internal Auditor. Auditing : A Journal of Practice E Theory, 14(1), 6486.

Krisnayanti, G., \& Riana, I. (2015). Pengaruh Keadilan Organisasional Terhadap Kepuasan Kerja Karyawan (Studi Kasus Pada BPR Lestari). E-Jurnal Manajemen Universitas Udayana.

Kurniawan, A. R. (2018). Pengaruh Karakteristik Aparat Pengawasan Intern Pemerintah (APIP) Terhadap Akuntabilitas Kinerja Instansi Pemerintah. Jurnal Akuntansi, 6(1), 1-20.

Mahayani, N., \& Merkusiwati, N. (2016). Pengaruh Persaingan Auditor Dan Sifat Machiavellian Pada Independensi Auditor Dengan Etika Profesi Sebagai Variabel Moderasi. E-Jurnal Akuntansi, 15(2), 1172-1200.

Murtini, N. N., \& Juliarsa, G. (2017). Pengaruh Independensi, Keahlian Profesional, Pengalaman Kerja, Dan Tingkat Pendidikan Pada Kinerja Pengawas Koperasi. E-Jurnal Akuntansi, 20(2), 1390-1418. https:// doi.org/10.24843/EJA.2017.v20.i02.p19

Novia, M. T., \& Ariyanto, D. (2016). Profesionalisme Sebagai Pemoderasi Pengaruh Independensi pada Kinerja Auditor. E-Jurnal Akuntansi, 14(3), 1895-1923.

Prabowo, P. P., \& Widanaputra, A. A. G. P. (2018). Pengaruh Love of Money, Machiavellian, dan Idealisme pada Persepsi Etis Mahasiswa Akuntansi. EJurnal Akuntansi. https:// doi.org/10.24843/eja.2018.v23.i01.p20

Pramono, O., \& Mustkawati, R. I. (2016). Pengaruh Locus Of Control, Due Professional Care Dan Integritas Terhadap Kualitas Audit (Studi Empiris 
Pada Kantor Akuntan Publik Di Daerah Istimewa Yogyakarta). Jurnal Profita Edisi 5, 1-15.

Prawitasari, P. P., \& Badera, I. D. N. (2015). Pengaruh Independensi, Keahlian Profesional, Dan Pengalaman Kerja Pada Kinerja Pengawas Koperasi Serba Usaha. E-Jurnal Akuntansi, 11(1), 15-28.

Putra, A. W. (2018). Engaruh Kompetensi, Independensi, Profesionalisme Auditor Internal Pemerintah Terhadap Kualitas Audit (Studi Kasus pada Auditor Perwakilan Badan Pengawasan Keuangan dan Pembangunan Daerah Istimewa Yogyakarta). Fakultas Ekonomi.

Putra, I. G. A. D., \& Wisadha, I. G. S. (2013). Pengaruh Profesionalisme, Independensi, Dan Pengalaman Auditor Pada Kualitas Audit Badan Pengawas Lembaga Perkreditan Desa (LPD). Jurnal Ilmiah Akuntansi Dan $\begin{array}{lll}\text { Bisnis, } & \text { 8(2), 89-97. }\end{array}$ https://ojs.unud.ac.id/index.php/jiab/article/view/10863/7672

Rahayu, S., \& Gudono. (2016). Faktor-Faktor yang Mempengaruhi Kemampuan Auditor dalam Pendeteksian Kecurangan : Sebuah Riset Campuran dengan Pendekatan Sekuensial Eksplanatif. Simposium Nasional Akuntansi XIX Lampung.

Rahma, F. (2012). Pengaruh profesionalisme, Etika Profesi, Tingkat Pendidikan, Independensi Auditor, Pengalaman Kerja, dan Budaya Kerja Auditor Terhadap Kinerja Auditor pada Kantor Akuntan Publik di Bali. Universitas Udayana.

Styawati, M. M. (2009). Pengaruh Profesionalisme, Etika Profesi, Tingkat Pendidikan, dan Pengalaman Kerja terhadap Kinerja Auditor (Studi pada BPKP Perwakilan Provensi Bali). Universitas Udayana.

Sugiyono. (2017). Metode Penelitian Bisnis. CV. Alfabeta.

Suryadharma, Adi, M., Riana, G., \& Sintaasih, Ketut, D. (2016). Pengaruh Kepemimpinan Dan Kompensasi Terhadap Kepuasan Kerja Dan Kinerja Karyawan (Studi Pada Pt. Bpr Sri Artha Lestari Denpasar). E-Jurnal Ekonomi Dan Bisnis Universitas Udayana.

Wijana, D. G. A., \& Ramantha, I. W. (2015). Integritas Sebagai Pemoderasi Pengaruh Komitmen Organisasi Pada Kinerja Auditor. E-Jurnal Akuntansi, 10(3), 841-851.

Yuen, D. C. Y., Law, P. K. F., Lu, C., \& Guan, J. Q. (2013). Dysfunctional auditing behaviour: Empirical evidence on auditors' behaviour in Macau. International Journal of Accounting and Information Management. https:/ / doi.org/10.1108/IJAIM-12-2012-0075 